\title{
THE EFFECT OF DECREASED PROTEIN LEVELS IN SOW DIETS ON NITROGEN CONTENT OF FAECES AND PHYSIOLOGICAL PARAMETERS OF BLOOD*
}

\author{
Daniel Korniewicz ${ }^{1}$, Eugeniusz R. Grela ${ }^{2}$, Jan Matras ${ }^{2}$, \\ Paweł Gajewczyk ${ }^{3}$, Zbigniew Dobrzański ${ }^{4}$, Adolf Korniewicz ${ }^{5}$, \\ Krystian Antkowiak ${ }^{1}$ \\ ${ }^{1}$ Cargill Ltd., Rolna 2/4, 62-280 Kiszkowo, Poland \\ ${ }^{2}$ Institute of Animal Nutrition and Bromatology, University of Life Sciences in Lublin, \\ Akademicka 13, 20-934 Lublin, Poland \\ ${ }^{3}$ Institute of Animal Breeding, Wrocław University of Environmental and Life Sciences, \\ Chełmońskiego 38C, 51-630 Wrocław, Poland \\ ${ }^{4}$ Department of Environmental Hygiene and Animal Welfare, Wrocław University of Environmental \\ and Life Sciences, Chełmońskiego 38C, 51-630 Wrocław, Poland \\ ${ }^{5}$ Department of Animal Nutrition and Feed Management, Wrocław University of Environmental \\ and Life Sciences, Chełmońskiego 38C, 51-630 Wrocław, Poland
}

\begin{abstract}
The research material consisted of 42 sows divided into 3 feeding groups, 14 individuals in each group, which received feed mixtures with different protein levels. Protein and amino acid levels in the control group were in accordance with recommendations contained in Polish standards. The level of protein in experimental groups was decreased by 10 and $20 \%$, respectively, and the levels of lysine, methionine, threonine and tryptophan were adjusted to those of the control group. During the gestation and lactation periods all sows were fed individually. The content of dry matter, nitrogen, fibre, fat and ash was determined in samples of faeces collected at 60 and 105 days of pregnancy, and the total nitrogen content was assessed in urine. Blood from sows was collected on day 14 of lactation, and indices of protein, fat transformation and mineral components content were determined in blood serum. The results of the analysis of faeces and urine prove that pregnant sows from the experimental groups excreted $7 \%$ and $10 \%$ less nitrogen in faeces, and $18 \%$ and $23 \%$ less urine in faeces. The reduced protein level in feed mixtures did not significantly influence the content of dry matter, fibre and ash in faeces. A significant decrease in the content of total protein, globulins, urea and an increase in cholesterol level was observed in the blood serum of sows from both experimental groups. No influence of the reduced protein level in feed on the content of mineral compounds in blood serum or haematological parameters of the sows' blood was noted.
\end{abstract}

Key words: sows, protein, nitrogen, faeces, urine, blood

*The present study was conducted within the framework of the research project No. PBZ-MEiN$5 / 2 / 2006$, financed by the Polish Ministry of Science and Higher Education. 
Cereal grain is the basic feed material providing protein and energy to pigs. Protein and exogenous amino acid deficiencies are commonly corrected by adding good, but expensive, imported extracted soybean meal. Thus, the contribution of that protein fodder needs to be strictly optimised, not only due to economic, but also physiological and ecological reasons.

Based on numerous feeding experiments (Reynolds and O’Doherty, 2006; Htoo et al., 2007; Korniewicz et al., 2007 b, c), it has been demonstrated that the amount of nitrogen retained in pig organisms is only $40-58 \%$ of the amount consumed with feed. The remaining $52 \%$ of the nitrogen is excreted with faeces and urine, presenting a considerable threat to the environment.

Nitrogen content in pig faeces depends mainly on the level and quality of protein in the given feed. As demonstrated in studies conducted on fatteners (Halas et al., 2003; Skiba et al., 2009), the emission of nitrogen into the environment may be reduced by lowering the total protein level in the diet, but with a concomitant increase in the level of exogenous amino acids added in crystalline form.

Canh et al. (1998) demonstrated that lowering the total protein level from 16.5\% to $12.5 \%$ in feed mixtures for fatteners, with simultaneous supplementation of exogenous amino acids did not influence body mass gains; however, it limited $\mathrm{N}$ excretion with urine and increased its retention with respect to the amount consumed. Similar results were obtained in the studies conducted by Portejoie et al. (2004) and Reynolds and O’Doherty (2006).

Le et al. (2009) used mixtures containing $15 \%$ and $12 \%$ protein with maintained amino acid levels in pig feed. The authors did not observe any influence of analysed protein levels on the digestibility of basic nutrients. At the same time they demonstrated the considerable odour reduction at lower protein levels. Similar effects of ammonia level reduction in faeces were demonstrated by Le et al. (2007 a, b), who supplemented the diet with crystalline amino acids.

There are few studies concerning the influence of limited protein levels in mixtures for sows on nutrient digestibility, blood characteristics and the amount of nitrogen excreted into the environment (faeces, urine). Feeding method (technology) as well as quality of feeds may also have an impact on nitrogen content in excreta, animal performance and blood parameters (Burek and Grela, 2005; Clowes et al., 2003).

The aim of the present study was to determine the influence of decreased protein levels in the feeding of pregnant and lactating sows on nutrient utilisation, content of nitrogen in excreta and the physiological parameters of blood.

\section{Material and methods}

\section{Animals and feeds}

The experiment was conducted at POL-LEAN Ltd.. Pig Farm in Łosice (Poland). The research material consisted of 42 sows (Polish Large White $\times$ Polish Landrace) that were inseminated over a period of 5 days. The insemination of all sows was 
conducted twice with boar semen (Hampshire $\times$ Pietrain) containing 4-5 bln of spermatozoa in each dose. After insemination, the sows were divided into 3 groups, 14 animals per group, taking into consideration farrowing order and previous reproductive performance (1st lactation - 4 sows; 2 nd lactation - 3 sows; 3rd lactation 2 sows; 4th lactation -3 sows; 5 th lactation -2 sows).

The division of sows into the 3 feeding groups was based on total protein level in feed mixtures for early pregnant sows, and in feed mixtures for late pregnant and lactating sows.

Group I - control, level of protein and amino acids recommended in accordance with Polish Standards (1993).

Group II - protein level decreased by $10 \%$, supplemented with lysine and methionine, threonine and tryptophan to the level recommended in accordance with Polish Standards (1993).

Group III - protein level decreased by $20 \%$, supplemented with lysine and methionine, threonine and tryptophan to the level recommended in accordance with Polish Standards (1993).

Tables 1 and 2 present the established level of total protein and amino acids, crude fibre and energy in $1 \mathrm{~kg}$ of feed mixtures for pregnant sows from particular groups, while Table 3 presents the values for lactating sows.

Table 1. Crude protein content in feed mixture for sows (\%)

\begin{tabular}{l|c|c|c}
\hline \multirow{2}{*}{ Sow } & \multicolumn{3}{c}{ Group } \\
\cline { 2 - 4 } & $\begin{array}{c}\text { I } \\
\text { Control }\end{array}$ & $\begin{array}{c}\text { II } \\
\text { Protein reduction } \\
-10 \%\end{array}$ & $\begin{array}{c}\text { III } \\
\text { Protein reduction } \\
-20 \%\end{array}$ \\
\hline Early pregnancy & 13.0 & 11.7 & 10.4 \\
Late pregnancy & 17.0 & 15.3 & 13.6 \\
Lactation & 17.0 & 15.3 & 13.6 \\
\hline
\end{tabular}

Table 2. Amino acid content (\%) and energy value of feed mixture for early pregnant sows

\begin{tabular}{l|c|c|c}
\hline \multirow{2}{*}{\multicolumn{1}{c|}{ Item }} & \multicolumn{3}{c}{ Group } \\
\cline { 2 - 4 } & I & $\begin{array}{c}\text { II } \\
\text { Control }\end{array}$ & $\begin{array}{c}\text { III } \\
\text { Protein reduction } \\
\text { Protein reduction } \\
\end{array}$ \\
\cline { 2 - 4 } & 13.0 & $10 \%$ & $-20 \%$ \\
\hline Crude protein & 0.64 & 0.64 & 10.4 \\
Lysine & 0.20 & 0.20 & 0.64 \\
Methionine & 0.46 & 0.45 & 0.20 \\
Methionine and cystine & 0.48 & 0.48 & 0.45 \\
Threonine & 0.15 & 0.15 & 0.48 \\
Tryptophan & 0.65 & 0.58 & 0.15 \\
Valine & 9.96 & 10.0 & 9.55 \\
Crude fibre & 2050 & 2050 & 2050 \\
Net energy (kcal/kg) & 11.6 & 11.9 & 11.9 \\
Metabolizable energy (MJ/kg) & & &
\end{tabular}


Table 3. Amino acid content (\%) and energy value of feed mixture for late pregnant and lactating sows

\begin{tabular}{l|c|c|c}
\hline \multirow{2}{*}{\multicolumn{1}{c}{ Item }} & \multicolumn{2}{c}{ Group } \\
\cline { 2 - 4 } & I & II & III \\
& Control & Protein reduction & $\begin{array}{c}\text { Protein reduction } \\
-20 \%\end{array}$ \\
\hline Crude protein & 17.0 & $-10 \%$ & 14.5 \\
Lysine & 0.87 & 15.3 & 0.87 \\
Methionine & 0.28 & 0.87 & 0.28 \\
Methionine and cystine & 0.60 & 0.28 & 0.57 \\
Threonine & 0.58 & 0.58 & 0.58 \\
Tryptophan & 0.21 & 0.58 & 0.21 \\
Valine & 0.81 & 0.21 & 0.65 \\
Crude fibre & 3.99 & 0.70 & 3.91 \\
Net energy (kcal/kg) & 2250 & 3.94 & 2250 \\
Metabolizable energy $(\mathrm{MJ} / \mathrm{kg})$ & 13.10 & 2250 & 13.10 \\
\hline
\end{tabular}

Feed mixtures for all groups were produced from the same components according to the original recipe at the "PIAST" Feed Plant in Lewkowiec (Poland) in cooperation with the Institute of Animal Nutrition and Bromatology, University of Life Sciences in Lublin (Poland).

The basal ingredients of mixtures were ground barley and wheat, beet pulp, extracted soybean meal and rapeseed oil. The level of total protein in mixtures for experimental groups was decreased by the limitation of extracted soybean meal contribution. Amino acids like lysine, methionine, threonine and tryptophan optimised in mixtures, were equalised to the level recommended in Polish Standards for Pig Feed (1993) by their addition in crystalline form. Mineral components and vitamins were supplemented to the recommended level by the addition of $0.3 \%$ of premix, manufactured at Cargill Poland Ltd. Kiszkowo, according to an original recipe.

The components used for the production of feed mixtures were subjected to chemical analysis determining the content of basic nutrients (AOAC, 2006) in the laboratory of Cargill Poland Ltd., and amino acid composition of protein in feed mixtures was determined using chromatographic method in a laboratory at Degussa AG Hanau-Wolfgang (Germany). Based on the results of the analysis, the optimisation of nutrient content in all mixtures for all groups was done according to experimental design.

The energy value of mixtures was calculated on the basis of analysis of components and digestibility indices and equations contained in Polish Standards for Pig Feed (1993) and CVB (2004).

Detailed composition of feed mixtures for pregnant and lactating sows, and the content of nutrients in $1 \mathrm{~kg}$ of these mixtures are presented in another paper (Gajewczyk et al., 2010).

\section{Management conditions}

The sows used in the experiment were placed in individual pens, where they were kept until 60 and 105 days of pregnancy, and then were moved to a farrowing house, where they stayed until the 28th day of lactation. After the weaning of piglets, the sows were placed in the mating sector of collective pens in contact with boars 
in order to induce oestrus. After exhibition of oestrus they were placed in individual pens and inseminated.

Farrowing pens were equipped with separate nipple drinkers for sows and piglets. Infrared radiators were installed above the mats as a heat source in the part of the pen for piglets. Parturition of sows took place without any help from handlers. Piglets reared by sows from all groups were treated in the same manner. The castration of boar piglets was done on the first day of life. Weaned piglets were moved to collective pens in a pig rearing building. Litters up to 11 individuals in each were equalised within each of the groups.

\section{Feeding schedule}

Daily doses of feed mixtures in particular physiological periods were as follows:

- during the period of early pregnancy from 1 to 90 days of pregnancy $-2.5 \mathrm{~kg}$;

- during the period of late pregnancy from 91 to 110 days of pregnancy $-3.5 \mathrm{~kg}$;

- during the period from the 111 th day of pregnancy to the 2 nd day before farrowing $-2.0 \mathrm{~kg}$;

- during the period from the 2 nd day before farrowing to farrowing $-1.0 \mathrm{~kg}$;

- on the day of farrowing - liquid mixture from wheat bran;

- on the 1 st day after farrowing $-1.0 \mathrm{~kg}$;

- on the 2 nd day after farrowing $-2.0 \mathrm{~kg}$;

- during the further period of lactation ad libitum (auto-feeder);

- on the day of weaning $-2 \mathrm{~kg}$;

- from weaning to mating $-4 \mathrm{~kg}$.

Early pregnant sows were fed individually from mating to 90 days of pregnancy with loose feeds in the amount of $2.5 \mathrm{~kg}$ given once a day by hand into troughs. Late pregnant sows, from 91 to 105 days of pregnancy were fed individually with pelleted diet in the amount of $3.5 \mathrm{~kg} /$ day/head given by hand into troughs twice a day. Nursing sows in the farrowing house were fed ad libitum with mixtures in pellet form from auto-feeder.

Additional feeding of piglets started from 7 days of age with the same mixture of "prestarter" type in pellet form that was given ad libitum up to 28 days of age.

\section{Information collected}

The influence of decreased protein level in mixtures on the amount of nitrogen excreted to the environment was determined on the basis of faeces and urine analysis. Faeces and urine samples were collected from 8 sows from each group at 60 and 105 days of pregnancy.

Faeces were collected directly from rectum and urine into plastic containers when sows excreted it in the morning. 10\% sulphuric acid was added to the collected samples of faeces and urine to bind ammonia. The samples were cold stored at $3-4^{\circ} \mathrm{C}$. The faeces, collected over 4 days, were thoroughly mixed and the collected samples ( $1 \mathrm{~kg}$ of faeces, 11 of urine) were subjected to chemical analyses. Faecal and urine nitrogen was determined according to Kiejdahl (AOAC, 2006) using Kjeltec 2300 analyser. 
The content of dry matter and total nitrogen was determined in samples of fresh faeces, while crude fibre, crude fat and crude ash content was analysed in dry samples. The content of total nitrogen was determined in urine samples. The above analyses were done in the chemical laboratory of the Department of Animal Nutrition and Feed Management, Wrocław University of Environmental and Life Sciences (WUELS).

The influence of decreased protein levels in mixtures for pregnant and lactating sows on physiological parameters was determined on the basis of chemical analyses of blood serum and haematological analyses. Blood from the jugular vein was collected from 30 sows (10 from each group) on 14th day of lactation, and after the separation of serum, the following biochemical components were determined in it: total protein, albumins, globulins, urea, glucose, enzymatic activity of ASP and ALP, triglycerides, cholesterol and its HDL and LDL fractions, phosphorus, sodium, chlorine, copper, zinc and iron. The analyses were performed in the biochemical laboratory of the Department of Environment and Animal Welfare, WUELS, using a Pentra 400 biochemical analyser manufactured by Horiba HBX with the proper reagents.

\section{Statistical analysis}

The results were presented as arithmetic means and standard deviations. The collected results of the study were analysed statistically using one-factor analysis of variance. Significance of differences between the groups was determined with Duncan's multiple range test, using Statgraphics v. 5.0. software.

\section{Results}

\section{Assessment of mixtures}

As mentioned above, particular ingredients of mixtures were subjected to chemical analysis. The results of analysis were the basis for optimising established levels of particular nutrients. Mixtures produced for pregnant and lactating sows were again subjected to chemical analysis. The analysis confirmed a consistency with research assumptions in terms of protein and exogenous amino acids level in particular feeding groups.

The content of mineral components and vitamins in $1 \mathrm{~kg}$ of feed mixtures for pregnant and lactating sows for all feeding groups was the same and consistent with the upper limit recommended in Polish Standards for Pig Feed (1993) and Dutch (2004) standards.

\section{Utilisation of nutrients from mixtures}

Because the established daily doses of mixtures for pregnant sows were fully eaten in all the groups, it may be concluded that they influence production and technological effects. The utilisation of basic nutrients from given feed mixtures by sows was documented on the basis of chemical analysis of faeces and urine excreted. Those analyses concerned the period of early pregnancy (60th day of pregnancy) and 
late pregnancy (105th day) and the results are compiled separately for each period of pregnancy.

In the period of early pregnancy (Table 4) faeces excreted by sows from all the groups were characterised by a similar content of dry matter (27.08-27.36\%).

Table 4. Nutrient content in $1 \mathrm{~kg}$ of faeces dry matter and nitrogen content in wet faeces and urine of early pregnant sows (60th day of pregnancy) $(\overline{\mathrm{x}} \pm \mathrm{SD})$

\begin{tabular}{|c|c|c|c|}
\hline \multirow[b]{2}{*}{ Nutrients (\%) } & \multicolumn{3}{|c|}{ Group } \\
\hline & $\begin{array}{c}\text { I } \\
\text { Control }\end{array}$ & $\begin{array}{c}\text { II } \\
\text { Protein reduction } \\
-10 \%\end{array}$ & $\begin{array}{c}\text { III } \\
\text { Protein reduction } \\
-20 \%\end{array}$ \\
\hline Dry matter & $27.36 \pm 3.54$ & $27.08 \pm 3.16$ & $27.27 \pm 3.62$ \\
\hline Crude protein & $\begin{array}{c}16.11 \pm 2.48 \\
100.0\end{array}$ & $\begin{array}{c}14.97 \pm 0.96 \\
92.9\end{array}$ & $\begin{array}{c}14.51 \pm 2.14 \\
90.0\end{array}$ \\
\hline Crude fibre & $\begin{array}{c}21.48 \pm 2.06 \\
100.0\end{array}$ & $\begin{array}{c}22.47 \pm 1.40 \\
104.6\end{array}$ & $\begin{array}{c}22.01 \pm 1.44 \\
102.5\end{array}$ \\
\hline Crude fat & $\begin{array}{c}4.11 \pm 0.55 \\
\quad 100.0\end{array}$ & $\begin{array}{c}3.62 \pm 0.75 \\
88.1\end{array}$ & $\begin{array}{c}3.86 \pm 0.48 \\
93.9\end{array}$ \\
\hline Crude ash & $\begin{array}{c}15.08 \pm 1.28 \\
100.0\end{array}$ & $\begin{array}{c}14.14 \pm 1.19 \\
93.7\end{array}$ & $\begin{array}{c}13.62 \pm 1.59 \\
90.3\end{array}$ \\
\hline $\begin{array}{c}\text { Content of } \mathrm{N} \text { in: } \\
\text { wet faeces }\end{array}$ & $\begin{array}{c}0.695 \mathrm{a} \pm 0.087 \\
100.0\end{array}$ & $\begin{array}{c}0.647 \pm 0.056 \\
93.1\end{array}$ & $\begin{array}{c}0.623 \mathrm{~b} \pm 0.042 \\
89.6\end{array}$ \\
\hline urine & $\begin{array}{c}0.872 \mathrm{~A} \pm 0.185 \\
100.0\end{array}$ & $\begin{array}{c}0.716 \mathrm{~B} \pm 0.167 \\
82.1\end{array}$ & $\begin{array}{c}0.668 \mathrm{~B} \pm 0.136 \\
76.6\end{array}$ \\
\hline
\end{tabular}
$\mathrm{P} \leq 0.01)$.

Values with the same letters and with no letters do not differ significantly $(\mathrm{a}, \mathrm{b}-\mathrm{P} \leq 0.05$ and $\mathrm{A}, \mathrm{B}-$

Total protein content in the faeces dry matter of sows from the control group was $16.1 \%$, while in experimental groups the level of that component was by 7 and $10 \%$ lower, which is the result of a reduced protein level in mixtures given, but the differences were not confirmed statistically $(\mathrm{P}>0.05)$.

The content of crude fibre in faeces of sows from all the groups was similar, but slightly higher in experimental groups. It may thus be concluded that reduced protein level deteriorates fibre utilisation. Crude fat in faeces of sows from the control group was at the level of $4.1 \%$, and in experimental groups its level was $11 \%$ and $6 \%$ lower, which may indicate better fat utilisation with decreased protein levels.

Crude ash level in faeces dry matter from the control group sows was $15 \%$, and in the experimental group it was by $6.3 \%$ and $9.7 \%$ lower.

Nitrogen $(\mathrm{N})$ content in $1 \mathrm{~kg}$ of wet faeces from the control group sows amounted to $0.695 \mathrm{~g} / \mathrm{N}$, and in experimental groups it was $6.9 \%$ and $10.4 \%$ lower, proportionally to the decrease in protein content in feed mixtures. Pigs excrete more nitrogen in urine compared to faeces. Thus, the influence of protein levels in mixtures fed to the pigs was very clear. Sows from the control group excreted $0.872 \mathrm{~g} / \mathrm{N}$ in $1 \mathrm{~kg}$ of 
urine, and in experimental groups that level was lower by $17.9 \%$ and $23.4 \%$. The differences observed between the control and experimental groups were confirmed statistically $(\mathrm{P} \leq 0.01)$.

In the period of late pregnancy (Table 5), faeces excreted by sows contained a lower amount of dry matter $(24.16 \%)$ than in the period of early pregnancy.

Table 5. Nutrient content in $1 \mathrm{~kg}$ of faeces dry matter and nitrogen content in wet faeces and urine of late pregnant sows (105th day of pregnancy) $(\overline{\mathrm{x}} \pm \mathrm{SD})$

\begin{tabular}{|c|c|c|c|}
\hline \multirow[b]{2}{*}{ Nutrients (\%) } & \multicolumn{3}{|c|}{ Group } \\
\hline & $\begin{array}{c}\text { I } \\
\text { Control }\end{array}$ & $\begin{array}{c}\text { II } \\
\text { Protein reduction } \\
-10 \%\end{array}$ & $\begin{array}{c}\text { III } \\
\text { Protein reduction } \\
-20 \%\end{array}$ \\
\hline Dry matter & $24.16 \pm 1.68$ & $23.81 \pm 0.76$ & $24.50 \pm 1.79$ \\
\hline Crude protein & $\begin{array}{c}17.86 \pm 1.09 \\
100.0\end{array}$ & $\begin{array}{c}17.32 \pm 0.76 \\
97.0\end{array}$ & $\begin{array}{c}16.59 \pm 0.92 \\
92.9\end{array}$ \\
\hline Crude fibre & $\begin{array}{c}20.29 \pm 1.73 \\
100.0\end{array}$ & $\begin{array}{c}20.20 \pm 1.13 \\
96.2\end{array}$ & $\begin{array}{c}20.15 \pm 1.68 \\
96.0\end{array}$ \\
\hline Crude fat & $\begin{array}{c}4.71 \mathrm{a} \pm 0.89 \\
100.0\end{array}$ & $\begin{array}{c}5.47 \pm 0.89 \\
116.1\end{array}$ & $\begin{array}{c}6.56 \mathrm{~b} \pm 1.20 \\
139.3\end{array}$ \\
\hline Crude ash & $\begin{array}{c}19.6 \pm 0.92 \\
100.0\end{array}$ & $\begin{array}{c}19.69 \pm 1.51 \\
100.4\end{array}$ & $\begin{array}{c}18.79 \pm 1.15 \\
95.8\end{array}$ \\
\hline $\begin{array}{l}\text { Content of } \mathrm{N} \text { in: } \\
\text { wet faeces }\end{array}$ & $\begin{array}{c}0.689 \pm 0.036 \\
100.0\end{array}$ & $\begin{array}{c}0.660 \pm 0.027 \\
95.8\end{array}$ & $\begin{array}{c}0.651 \pm 0.058 \\
94.5\end{array}$ \\
\hline urine & $\begin{array}{c}0.785 \mathrm{~A} \pm 0.190 \\
100.0\end{array}$ & $\begin{array}{c}0.656 \mathrm{~B} \pm 0.087 \\
83.6\end{array}$ & $\begin{array}{c}0.615 \mathrm{~B} \pm 0.029 \\
78.3\end{array}$ \\
\hline
\end{tabular}

Values with the same letters and with no letters do not differ significantly $(\mathrm{a}, \mathrm{b}-\mathrm{P} \leq 0.05$ and $\mathrm{A}, \mathrm{B}-$ $\mathrm{P} \leq 0.01)$

Total protein level in faeces dry matter of sows from the control group was $17.86 \%$, so it was higher when compared to the period of early pregnancy $(16.11 \%)$. This results from the fact that feed mixture for sows in the period of early pregnancy contained only $13 \%$ protein, and the mixture for late pregnant sows contained $17 \%$ of this nutrient. Sows from the experimental groups excreted the faeces containing $3.0 \%$ and $6.1 \%$ less protein in groups II and III, respectively, than those from experimental groups.

The content of crude fibre in faeces dry matter of sows from the control group $(20.3 \%)$ was similar to the level from the period of early pregnancy. In faeces of sows from experimental groups, a $4.0 \%$ decrease in fibre content was observed, unlike in the period of early pregnancy. The difference could have been caused by the fact that mixtures fed during the period of late pregnancy were in pellet form, while during the period of early pregnancy they were in loose form. Moreover, the mixtures for the period of early pregnancy contained $10 \%$ fibre, while mixtures for late 
pregnant and lactating sows contained only 3.5\% fibre. That may be the reason for the differences between periods of pregnancy concerning fibre excreted in faeces. Crude fat in the faeces of sows from the control group was $4.7 \%$, and in experimental groups its level was $16 \%$ and $39 \%$ higher.

No significant differences between feeding groups in terms of crude ash content in faeces excreted were noted. Nitrogen $(\mathrm{N})$ content in $1 \mathrm{~kg}$ of wet faeces from control sows $(0.689 \mathrm{~g} \mathrm{~N})$ was very similar to the content in faeces of control sows in the period of early pregnancy $(0.695 \mathrm{~g} \mathrm{~N})$. Sows from experimental groups excreted in faeces $4.2 \%$ and $5.5 \%$ less nitrogen in groups II and III, respectively. The decrease in $\mathrm{N}$ content in faeces of sows from experimental groups was higher than in the period of early pregnancy.

The content of nitrogen in $1 \mathrm{~kg}$ of urine excreted by sows from the control group $(0.785 \mathrm{~g} \mathrm{~N})$ was lower by $10 \%$ compared to urine from the period of early pregnancy $(0.872 \mathrm{~g} \mathrm{~N})$. Sows from the experimental groups excreted less nitrogen in the period of late pregnancy as compared to the control group, by $16.4 \%$ and $21.7 \%$ in groups II and III, respectively.

\section{Biochemical and haematological parameters}

The results obtained from the blood serum analysis presented in Table 6 indicate that the reduction of protein level in mixtures had an influence on the indices of protein transformation. A significant decrease in total protein level from 84.4 to $77.4 \mathrm{~g} / \mathrm{l}$, and a decrease in globulin level from 48.8 to $41.5 \mathrm{~g} / \mathrm{l}$ were observed. Urea content in blood serum of sows from the control group was $7.4 \mathrm{mmol} / \mathrm{l}$, and in experimental groups with reduced protein level, a proportional decrease in urea level to 5.9 $(\mathrm{P} \leq 0.05)$ and $4.7 \mathrm{mmol} / \mathrm{l}$ was noted $(\mathrm{P} \leq 0.01)$.

Table 6. Biochemical indices of sow blood serum $(\overline{\mathrm{x}} \pm \mathrm{SD})$

\begin{tabular}{l|r|r|r}
\hline \multirow{2}{*}{\multicolumn{1}{c}{ Indices }} & \multicolumn{2}{c}{ Group } & \multicolumn{1}{c}{ III } \\
\cline { 2 - 4 } & \multicolumn{1}{c}{$\begin{array}{c}\text { II } \\
\text { Control }\end{array}$} & $\begin{array}{c}\text { Protein reduction } \\
-10 \%\end{array}$ & $\begin{array}{c}\text { Protein reduction } \\
-20 \%\end{array}$ \\
\hline Total protein (g/l) & $84.41 \mathrm{a} \pm 7.40$ & $79.75 \pm 8.06$ & $77.43 \mathrm{~b} \pm 4.18$ \\
Albumins (g/l) & $35.56 \pm 1.85$ & $37.81 \pm 1.51$ & $35.94 \pm 1.44$ \\
Globulins (g/l) & $48.85 \mathrm{a} \pm 7.74$ & $41.94 \mathrm{~b} \pm 7.30$ & $41.49 \mathrm{~b} \pm 3.30$ \\
AST (U/L) & $37.23 \pm 8.78$ & $31.70 \pm 5.40$ & $30.33 \pm 3.89$ \\
ALT (U/L) & $40.65 \pm 6.26$ & $41.49 \pm 4.91$ & $40.66 \pm 6.40$ \\
Urea (mmol/l) & $7.41 \mathrm{aA} \pm 1.13$ & $5.86 \mathrm{~b} \pm 0.92$ & $4.68 \mathrm{~B} \pm 0.85$ \\
Glucose (mmol/1) & $3.05 \mathrm{a} \pm 0.75$ & $3.47 \pm 1.35$ & $4.49 \mathrm{~b} \pm 1.20$ \\
Triglycerides (mmol/l) & $0.27 \pm 0.11$ & $0.27 \pm 0.11$ & $0.27 \pm 0.10$ \\
Total cholesterol (mmol/l) & $1.88 \mathrm{a} \pm 0.33$ & $2.22 \mathrm{~b} \pm 0.28$ & $2.22 \mathrm{~b} \pm 0.47$ \\
HDL cholesterol (mmol/l) & $1.03 \pm 0.19$ & $1.14 \pm 0.16$ & $1.09 \pm 0.24$ \\
LDL cholesterol (mmol/1) & $0.83 \mathrm{a} \pm 0.15$ & $0.97 \mathrm{~b} \pm 0.14$ & $0.98 \mathrm{~b} \pm 0.24$ \\
\hline
\end{tabular}

Values with the same letters and with no letters do not differ significantly $(\mathrm{a}, \mathrm{b}-\mathrm{P} \leq 0.05$ and $\mathrm{A}, \mathrm{B}-$ $\mathrm{P} \leq 0.01)$. 
The further effect of protein reduction in mixtures given was a decrease in enzymatic activity of AST from 37.2 to $30.4 \mathrm{U} / \mathrm{L}$. However, no differences in alanine transaminase (ALT) activity were noted.

The results obtained also prove the beneficial influence of reduced protein levels with the addition of exogenous amino acids on the increase in glucose concentrations from 3.05 to 3.47 and $4.49 \mathrm{mmol} / \mathrm{l}$. It may thus be concluded that this kind of feeding influences energy balances in sows. Significant increase in total cholesterol level from 1.88 to $2.22 \mathrm{mmol} / \mathrm{l}$ and in LDL fraction from 0.83 to $0.98 \mathrm{mmol} / 1$ were observed in blood serum of sows fed mixtures with reduced protein level.

The results of blood analysis concerning mineral components, presented in Table 7, demonstrate that protein levels in mixtures for sows did not influence significantly the level of macroelements analysed: $\mathrm{Ca}(2.52-2.58 \mathrm{mmol} / \mathrm{l})$, Mg (0.96-1.01 mmol/l), Na (140.96-141.19 mmol/1), P (2.27-2.48 mmol/l). Also, no significant differences in microelement content $(\mathrm{Cu}, \mathrm{Fe}, \mathrm{Zn})$ were noted between the groups.

Table 7. Content of minerals in blood serum $(\overline{\mathrm{x}} \pm \mathrm{SD})$

\begin{tabular}{l|c|c|c}
\hline \multirow{2}{*}{\multicolumn{1}{c}{ Indices }} & \multicolumn{3}{c}{ Group } \\
\cline { 2 - 4 } & \multicolumn{1}{c}{$\begin{array}{c}\text { I } \\
\text { Control }\end{array}$} & $\begin{array}{c}\text { II } \\
\text { Protein reduction } \\
-10 \%\end{array}$ & $\begin{array}{c}\text { III } \\
\text { Protein reduction } \\
-20 \%\end{array}$ \\
\hline $\mathrm{Na}(\mathrm{mmol} / \mathrm{l})$ & $141.19 \pm 1.15$ & $141.06 \pm 1.78$ & $140.96 \pm 1.55$ \\
$\mathrm{~K}(\mathrm{mmol} / \mathrm{l})$ & $5.82 \pm 0.47$ & $5.92 \pm 0.26$ & $6.06 \pm 0.50$ \\
$\mathrm{Chlorides}(\mathrm{mmol} / \mathrm{l})$ & $100.48 \pm 0.90$ & $101.75 \pm 1.10$ & $102.44 \pm 2.60$ \\
$\mathrm{Ca}(\mathrm{mmol} / \mathrm{l})$ & $2.52 \pm 0.06$ & $2.58 \pm 0.10$ & $2.53 \pm 0.08$ \\
$\mathrm{Mg}(\mathrm{mmol} / \mathrm{l})$ & $0.99 \pm 0.03$ & $1.01 \pm 0.06$ & $0.96 \pm 0.10$ \\
$\mathrm{P}(\mathrm{mmol} / \mathrm{l})$ & $2.27 \pm 0.14$ & $2.48 \pm 0.12$ & $2.37 \pm 0.19$ \\
$\mathrm{Fe}(\mu \mathrm{mol} / \mathrm{l})$ & $20.48 \pm 3.83$ & $25.48 \pm 1.98$ & $23.10 \pm 10.28$ \\
$\mathrm{Zn}(\mu \mathrm{mol} / \mathrm{l})$ & $6.71 \pm 0.68$ & $7.33 \pm 1.03$ & $7.17 \pm 1.88$ \\
$\mathrm{Cu}(\mu \mathrm{mol} / \mathrm{l})$ & $36.04 \pm 2.39$ & $37.81 \pm 4.58$ & $37.21 \pm 5.09$ \\
\hline
\end{tabular}

Values with the same letters and with no letters do not differ significantly $(\mathrm{a}, \mathrm{b}-\mathrm{P} \leq 0.05$ and $\mathrm{A}, \mathrm{B}-$ $\mathrm{P} \leq 0.01)$.

The results of haematological analysis of blood presented in Table 8 show that protein level applied in mixtures for sows did not influence the concentration of white blood cells (WBC), haemoglobin (HGB), haematocrit (HCT), and the content of erythrocytes (RBC). No differences between the control and experimental groups were noted as regards other indices connected with iron metabolism, namely mean erythrocyte volume (MCV), haemoglobin content in erythrocytes $(\mathrm{MCH})$, and mean haemoglobin concentration in erythrocytes (MCHC). 
Table 8. Haematological indices of sow blood $(\overline{\mathrm{x}} \pm \mathrm{SD})$

\begin{tabular}{l|c|c|c}
\hline \multirow{2}{*}{\multicolumn{1}{c}{ Indicators }} & \multicolumn{3}{c}{ Groups } \\
\cline { 2 - 4 } & $\begin{array}{c}\text { I } \\
\text { Control }\end{array}$ & $\begin{array}{c}\text { II } \\
\text { Protein reduction } \\
-10 \%\end{array}$ & $\begin{array}{c}\text { III } \\
\text { Protein reduction } \\
-20 \%\end{array}$ \\
\hline White blood cells (WBC) (G/l) & $16.21 \pm 35$ & $14.40 \pm 4.61$ & $17.30 \pm 2.86$ \\
Red blood cells (RBC) (T/l) & $5.04 \pm 0.45$ & $5.73 \pm 0.81$ & $5.62 \pm 1.22$ \\
Haemoglobin ((HGB) (mmol/l) & $6.73 \pm 0.41$ & $7.50 \pm 0.82$ & $7.25 \pm 1.41$ \\
Haematocrit (HCT) (1/1) & $0.35 \pm 0.02$ & $0.38 \pm 0.05$ & $0.37 \pm 0.08$ \\
Plates (PLT) (G/l) & $205.75 \pm 29.76$ & $237.88 \pm 28.22$ & $234.88 \pm 84.55$ \\
Mean corpuscular volume (MCV) (fl) & $70.00 \pm 5.24$ & $67.00 \pm 3.21$ & $65.88 \pm 3.60$ \\
Mean corpuscular haemoglobin (MCH) & $1.34 \pm 0.11$ & $1.32 \pm 0.07$ & $1.29 \pm 0.06$ \\
(fmol) & & & \\
Mean corpuscular haemoglobin & $19.18 \pm 0.49$ & $19.68 \pm 0.43$ & $19.61 \pm 0.51$ \\
concentration (MCHC) (mmol/l) & &
\end{tabular}

Values with the same letters and with no letters do not differ significantly $(\mathrm{a}, \mathrm{b}-\mathrm{P} \leq 0.05$ and $\mathrm{A}, \mathrm{B}-$ $\mathrm{P} \leq 0.01)$.

\section{Discussion}

Feed mixtures contained only $13 \%$ protein for control sows fed in the period of early pregnancy, and $17 \%$ protein for late pregnant and lactating sows. The mixtures also differed in amino acid content. Moreover, mixtures for pregnant sows given in loose form contained $9.6 \%$ fibre, and mixtures for late pregnant and lactating sows in pellet form contained only $3.5 \%$ fibre. The differences between mixtures for early and late pregnant sows influenced the amount of components excreted in faeces and urine of sows, determined at 60 and 105 days of pregnancy.

As demonstrated by Raj et al. (1997) on the basis of a digestibility study conducted on sows, the digestibility coefficients of ration dry matter was $65.6 \%$ with fibre content of $2.8 \%$, and when that level increased to $10.6 \%$ digestibility of dry matter decreased to $41.7 \%$.

Another study conducted by Raj and Fandrejewski (1997) analysed the influence of feed ration $(1.5,2.5$ and $3.5 \mathrm{~kg})$ given to pregnant sows at 2, 3 and 4 months of pregnancy on the digestibility of basic nutrients. It was demonstrated that digestibility of nutrients and energy did not depend on feeding level and period of pregnancy.

The results of the present study concerning fat content in faeces of early and late pregnant sows prove that fat is utilised less efficiently in the period of late pregnancy. The thesis may be confirmed by the study conducted by Raj and Fandrejewski (1997) who demonstrated that digestibility of fat in sows in the period of early pregnancy was $40.3 \%$, while in the period of late pregnancy it decreased to $22.8 \%$.

An interesting experiment was conducted by Clowes et al. (2003). Pregnant gilts were allocated over three successive parities, to the control, fed a $15 \% \mathrm{CP}$ diet, or phase-fed a 12,13 , and $16 \% \mathrm{CP}$ diet, respectively, in periods 1 (day 0-38), 
2 (day 39-74), and 3 (day 75-115) of gestation. Nitrogen balance was measured at the end of each period (control, phase-fed). In gestation, the significantly lower dietary $\mathrm{N}$ intake $(-9 \%)$, and faecal $(-7 \%)$ and urinary $\mathrm{N}(-9 \%)$ excretion in phasefed sows was reflected in lower $(-18 \%)$ plasma urea $N$ concentrations. Semeniuk and Grela (2011) showed that a 10\% reduction in protein and exogenous amino acid contents in fattening pig mixtures, decreased nitrogen emission to the environment by $3.5 \%$ (limited feeding) or by $8 \%$ (ad libitum feeding).

Feed additives may be considered as another way of reducing ammonia emission in faeces. As reported by Krasucki et al. (2004) an increase in digestibility indices of dry matter, fat and certain amino acids was observed with the addition of microbial phytase to mixtures for sows. Another study conducted by Korniewicz et al. (2006) demonstrated a significant decrease in protein content in finishing pig faeces from $23.23 \%$ (control group) to $20.46 \%$ with the $2 \%$ addition of halloysite to the standard diet. In a study on fatteners fed a diet with 10,20 or $30 \%$ reduced content of crude protein and exogenous amino acids (lysine, methionine, tryptophan, threonine), Grela and Kowalczuk-Vasilev (2010) noted significant (in comparison with control) decrease in faecal nitrogen (up to 34.9\%) and urinary nitrogen (up to $46.9 \%$ ) excretion.

The content of particular exogenous amino acids in the diet plays a very important role in feeding of sows with mixtures with reduced protein levels. As demonstrated by Pampuch (2003), an increasing concentration of standardised digestible tryptophan from 0.9 to $2.1 \mathrm{~g} / \mathrm{kg}$ of mixture for lactating sows caused a three-fold inhibition of body mass losses and a two-fold increase in feed intake. An increase in the level of digestible tryptophan prevented a reduction in serotonin levels in blood serum. Serotonin takes part in the regulation of appetite, and its level in the brain is correlated to the amount of tryptophan collected with feed. It should also be remembered that serotonin formation depends on the ratio of tryptophan to high-molecular neutral amino acids (phenylalanine, tyrosine, isoleucine, valine and leucine) and on the level of total protein in a diet. That relationship is especially important in the feeding of high-producing lactating sows that should consume large amounts of fodder.

The content of lysine, methionine, threonine and tryptophan, which were introduced in crystalline form, was optimised in the present study. The amount of Llysine added was almost 2-fold higher in group II, and 2.4-fold higher in group III; while the level of L-threonine was 3.7-fold higher in group II and as much as 3.7-fold higher in group III as compared to the control. When reducing protein levels via the removal of extracted soybean meal in experimental mixtures, a decrease in the level of another amino acid limiting the biological value of protein, i.e. valine (from 0.65 to $0.51 \%$ ), was observed. The deficiency of that amino acid would have affected the production obtained physiological effects, and this requires further study.

The biochemical blood parameters obtained in the present study point to the influence of protein reduction in the diet on protein and fat, blood parameters. Generally, they were within reference values given by Winnicka (2008). Decreasing the dietary protein level did not influence mineral or haematological parameters of blood. Czech and Grela (2004) revealed that different sources and activities of phytase had an im- 
pact on $\mathrm{Hb}, \mathrm{RBC}$ and $\mathrm{WBC}$ as well as on $\mathrm{AP}, \mathrm{AST}$ and $\mathrm{LDH}$ and contents of $\mathrm{P}, \mathrm{Na}$, $\mathrm{K}, \mathrm{Mg}, \mathrm{Fe}, \mathrm{Cu}$ and $\mathrm{Zn}$. The influence of dietary phytase on Ht or ALT was not noted. Reducing dietary protein level significantly decreased uric acid and creatinin levels in blood plasma, without changing total protein content (Semeniuk and Grela, 2011). In turn, Heath et al. (1991) claim that management conditions have significant effect on blood parameters (e.g. total proteins, bilirubin, creatine kinase, immunoglobulin concentrations).

A differentiation in biochemical blood parameters in swine, including mineral status, was observed under the influence of herbs or fat-mineral concentrate (Korniewicz et al., 2000; 2007 a) and other nutritional factors (Burek and Grela, 2005; Park et al., 2008; Wang et al., 2010).

In conclusion, the results obtained demonstrate that sows in gestation and lactation fed mixtures with protein level reduced by $10 \%$ or $20 \%$ and supplemented with amino acids in crystalline form, excreted significantly lower concentrations of nitrogen in their faeces and urine as compared to control groups. That fact is of crucial significance as regards the environmental protection issues.

The reduced protein level in feed mixtures did not influence the content of mineral components in serum and haematological parameters of blood. However, a significant decrease in total protein, globulins, urea level and an increase in cholesterol concentration was observed in blood serum of sows fed mixtures with decreased protein level.

\section{References}

AOAC (2006). Official Methods of Analysis of the Association of Official Analytical Chemists. 17th edition, Arlington, Virginia, USA.

B u re k R., Gre la E.R. (2005). Effect of different lactating sow feeding schedules on performance and some blood indices (in Polish). Med. Weter., 61 (7): 822-825.

Canh T.T., Aarnink A.J.A., Schulte J.B., Sutton A., Langhout D.J., Versterg e n M.W.A. (1998). Dietary protein affects nitrogen excretion and ammonia emission from slurry of growing-finishing pigs. Livest. Prod. Sci., 56: 181-191.

Clowe s E.J., Kirkwood R., Cegielski A., Aherne F.X. (2003). Phase-feeding protein to gestating sows over three parities reduced nitrogen excretion without affecting sow performance. Liv. Prod. Sci., 81(2-3): 235-246.

CVB. (2004). Veevoedertabel. Centtral Veevoederbureau, Lelystad, Holland.

Czech A., Grela E.R. (2004). Biochemical and haematological blood parameters of sows during pregnancy and lactation fed the diet with different source and activity of phytase. Anim. Feed Sci. Technol., 116: 211-223.

Gajewczyk P., Korniewicz D., Kołacz R., Dobrzański Z., Korniewicz A. (2010). Response of pregnant and lactating sows to reduced protein content in complete compound feed. Pol. J. Vet. Sci., 13 (4): 755-763.

Gre l a E.R., K o w a l c z u k - V a s i l e v E. (2010). Influence of digestible crude protein reduction and amino acids additive in growing pigs diets on their performance and nitrogen balance. Ann. UMCS., Zootechnica, 28 (1): 1-8.

Ha las V., B abins zky L., V e r st e ge n M.W.A. (2003). Conceptual paper for modelling protein and lipid accretion in different body parts of growing and fattening pigs. Arch. Anim. Nutr., 57 (2): $137-150$.

He at h M.F., Evan s R.J., Gre sh a m A.C.J. (1991). Blood biochemical reference ranges for sows under modern management conditions. Brit. Vet. J., 147 (4): 331-339. 
H t o o K., S a u r W.C., Zhang Y., Cervantes M., Li a o S.F., Araiza B.A., Morales A., Torrenter a N. (2007). The effect of feeding low-phytate barley-soybean meal diets differing in protein content to growing pigs on the excretion of phosphorus and nitrogen. J. Anim. Sci., 85: $700-705$.

Korniewicz A., Dobrzański Z., Kołacz R., Tronina S., Korniewicz D., Czarnik- Matusewicz H. (2000). Fish fat-mineral concentrate (FF-MC) in fatteners feeding. Rocz. Nauk. Zoot. Ann. Anim. Sci., 27: 143-160.

Korniewicz D., Kołacz R., Dobrzański Z., Korniewicz A., Kulok M. (2006). Effect of dietary halloysite on the quality of feed and utilization of nutrients by fatteners. EJPAU ser. Anim. Husb., 9(4).

Korniewicz D., Dobrzański Z., Korniewicz A., Kaczmarek P., Różański H., Pogoda-Sewerniak K. (2007 a). Influence of plant extracts (Herbiplant CS) on biochemical indices and mineral elements in blood serum of fatteners. Acta. Sci. Pol. ser. Med. Vet., 6: $35-43$.

Korniew i cz D., Dobrzańs ki Z., Chojnacka K., Korniewicz A., Kołacz R. (2007 b). Effect of dietary yeasts enriched with $\mathrm{Cu}, \mathrm{Fe}$ and $\mathrm{Mn}$ on digestibility of main nutrients and absorption of minerals by growing pigs. Am. J. Agric. Biol. Sci., 2 (4): 267-275.

Korniewicz D., Różański H., Dobrzański Z., Kaczmarek P., Korniewicz A. $(2007 \mathrm{c})$. Effect of Herbiplant CS preparation on basic nutrient digestibility and mineral balance and absorption in fatteners. Ann. Anim. Sci., 7: 259-271.

Krasucki W., Matras J., Grela E.R. (2004). Total and ileal digestibility of protein and amino acids of the sows diet supplemented with microbial phytase and citric acid. Acta Sci. Pol. ser. Zoot., 3 (2): 79-90.

Le P.D., Aarnink A.J.A., Jongbloed A.W., Van de Peet-Schwering C.M.C., Vers t e g e n M.W.A, O g in k N.W.M. (2007 a). Effects of dietary crude protein level on odour from pig manure. Animal, 1: 734-744.

Le P.D., Aarnink A.J.A., Jongbloed A.W., Van de Peet-Schwering C.M.C., O g in k N.W.M., V e r s te g en M.W.A. (2007 b). Effects of crystalline amino acid supplementation to the diet on odor from pig manure. J. Anim. Sci., 85: 791-801.

L e P.D., A a rn in k A.J.A., J o n g b l o e d A.W. (2009). Odour and ammonia emission from pig manure as affected by dietary crude protein level. Livest. Sci., 121: 267-274.

P a m p u c h F.G. (2003). The effects of varying supplemental levels of dietary tryptophan on lactation performance and different physiological parameters in lactating sows. Doktors der Agrarwissenschaften genehmigten Dissertation, Technische Universität München.

Park M.S., Yang Y.X., Choi J.Y., Y o on S.Y., Ahn S.S, Lee S.H., Y ang B.K., Le e J.K., $\mathrm{Ch}$ a e B.J. (2008). Effects of dietary fat inclusion at two energy levels on reproductive performance, milk compositions and blood profiles in lactating sows. Acta Agric. Scand. Sect. A., Anim. Sci., 58: 121-128.

Portejoie S., Dourmad J., Martinez J., Lebreton Y. (2004). Effect of lowering dietary crude protein on nitrogen excretion, manure composition and ammonia emission from fattening pigs. Livest. Prod. Sci., 91: 45-55.

Raj S., Fandrejewski H., Skiba G., Weremko D. (1997). Effect of crude fibre on energy digestibility in growing pigs and sows. Current rules of pigs feeding (2). Ed. IFiŻZ PAN, Jabłonna, pp. $156-159$.

R a j S., F a n d r e j e w s k i H. (1997). Effects of feeding level, stage of pregnancy and age on digestibility of energy by sows. Current rules of pigs feeding (2). Ed. IFiŻZ PAN, Jabłonna, pp. 160-162.

R e y n o ld s A.M., O ' D o h e r t y J.V. (2006). The effect of amino acid restriction during the grower phase on compensatory growth, carcass composition and nitrogen utilisation in grower-finisher pigs. Livest. Sci., 104: 112-120.

S e m e n i u k W., Gre la E.R. (2011). Effect of a reduced protein content in the nutrition of growingfinishing pigs fed a restricted or ad libitum diet on nitrogen parameters in their blood and urine (in Polish). Med. Weter., 67 (5): 339-342.

Skiba G., Raj S., W er e m k o D., F andrejewski H. (2009). Protein, nucleic acid content and activity of $\mu$ - and $\mathrm{m}$-calpain in the longissimus dorsi muscle as affected by protein and energy restriction during early growth of pigs. Archiv. Anim. Nutr., 63 (2): 149-159. 
W a n g Y., T a n g J.W., M a W.Q., F e n g J., F e n g J. (2010). Dietary zinc glycine chelate on growth performance, tissue mineral concentrations, and serum enzyme activity in weanling piglets. Biol. Trace Elem. Res., 133 (3): 325-334.

Accepted for printing 6 XII 2012

\section{DANIEL KORNIEWICZ, EUGENIUSZ R. GRELA, JAN MATRAS, PAWEL GAJEWCZYK, ZBIGNIEW DOBRZAŃSKI, ADOLF KORNIEWICZ, KRYSTIAN ANTKOWIAK}

\section{Wpływ obniżonego poziomu białka w paszy dla loch na zawartość azotu w odchodach i wskaźniki fizjologiczne krwi}

\section{STRESZCZENIE}

Celem podjętych badań było określenie wpływu obniżenia poziomu białka w mieszankach pełnoporcjowych dla loch prośnych i karmiących na zawartość azotu w odchodach oraz wskaźniki fizjologiczne krwi. Materiał badawczy stanowiły 42 lochy przydzielone do 3 grup żywieniowych. W grupie kontrolnej (I) poziom białka i aminokwasów był zgodny z zaleceniami zawartymi w polskich normach. W grupach doświadczalnych (II i III) obniżono poziom białka o 10 i 20\%, zwiększając zawartość lizyny, metioniny, treoniny i tryptofanu do poziomu grupy kontrolnej. Do wszystkich mieszanek dla loch prośnych i karmiących dodawano po $0,8 \%$ konserwantu wieloskładnikowego w postaci sypkiej. Wszystkie lochy w okresie ciąży i laktacji żywiono indywidualnie. W próbkach kału pobranych w 60. i 105. dniu ciąży oznaczono zawartość suchej masy, azotu, włókna i popiołu, a w moczu zawartość azotu. W 14. dniu laktacji pobrano od loch krew i oznaczono w surowicy wskaźniki biochemiczne krwi. Lochy grup II i III w 60. dniu prośności wydalały w kale mniej azotu o 4 i 7\%, a w moczu odpowiednio o 10 i 12. W okresie wysokiej prośności (105. dzień) wydalały w kale mniej azotu o 4 i 8\%, a w moczu odpowiednio o 16 i 30\%. W surowicy krwi loch obu grup doświadczalnych nastąpiło obniżenie zwartości białka całkowitego, globulin i mocznika oraz zwiększenie poziomu cholesterolu całkowitego i frakcji LDL. Poziom białka w podawanych mieszankach nie miał wpływu na zawartość składników mineralnych w surowicy oraz wskaźniki hematologiczne krwi. 